\title{
Zahraničněobchodní aspekty vstupu České republiky do Evropské unie
}

\author{
Lenka Nigrinová ${ }^{1}$
}

\section{1. Úvod}

Podepsáním Smlouvy o přistoupení České republiky k Evropské unii dne 16. dubna 2003 v Athénách se otevřela cesta k referendu, ve kterém se občané České republiky mohli vyslovit ke členství ČR v Evropské unii. Na základě výsledků referenda, konaného v polovině června 2003, se ČR se stala plnoprávným členem EU od 1. května 2004.

Vstupem ČR do EU je samozřejmě dotčena zahraničněobchodní politika ČR. Mezi povinné závazky patří přistoupení nových členských zemí k mezinárodním smlouvám, které EU a členské státy uzavřely se třetími zeměmi. Obchodní politika je vymezena z věcného i institucionálního hlediska především článkem 133 Smlouvy o založení ES a je označena za společnou. To znamená, že vychází z jednotných základů, mezi něž patří uzavírání obchodních a celních dohod, úprava celních sazeb, sjednocení liberalizačních opatření, vývozní politika a obchodní ochranná opatření. ${ }^{2}$

\section{Harmonizace české zahraničněobchodní politiky s obchodní politikou EU}

Při provádění Společné obchodní politiky (SOP) má velmi důležité postavení Rada a Komise. Komise má především iniciativní pravomoc, předkládá návrhy k provádění SOP ve dvoustranném i mnohostranném rozměru a sjednává mezinárodní obchodní dohody. Návrhy pak postupuje Radě, která rozhoduje o obchodně politických otázkách. Rada rozhoduje kvalifikovanou většinou, pouze v př́ípadech týkajících se zavádění konečných antidumpingových a vyrovnávacích opatření, se uplatňuje prostá většina. Jestliže je nutné dojednat nějaké obchodní otázky s mezinárodními organizacemi nebo třetími státy, pak Rada zmocňuje Komisi k zahájení jednání a také ji uděluje mandát pro tato jednání. Přitom konzultace Evropské komisi poskytuje zvláštní výbor ustavený Radou ${ }^{3}$ a dále teritoriálně a zbožově zaměřené skupiny. Pưvodní zakládající smlouvy ES byly v období počínaje koncem 80. let několikrát modifikovány. Výraznější změna týkající se Článku 133 Smlouvy o založení ES přinesla Smlouva z Nice. Nově totiž byla zařazena do výlučné kompetence

1 Ing. Lenka Nigrinová, interní doktorand Katedry mezinárodního obchodu Vysoké školy ekonomické v Praze.

2 Z analýzy provedené Českou podnikatelskou reprezentací při EU (CEBRE) bylo zjištěno, že firmy se lépe orientují ve změnách, které nastanou při obchodování se členskými státy EU (85\% firem částečně nebo téměř zcela zná nové procedury) než při obchodování se státy mimo EU. Podle ankety jsou hlavním zdrojem informací pro tyto subjekty hospodářské komory, dále pak oficiální zdroje státní správy jako jsou Ministerstvo průmyslu a obchodu, Generální ředitelství cel a celní úřady. Zástupci firem zmínili, že by bylo potřebné rozšířit informační činnost.

3 Výbor pro otázky Článku 133. 
ES jednání o dohodách, které se týkají služeb a komerčních aspektů práv k duševnímu vlastnictví. V těchto otázkách se rozhodnutí přijímají kvalifikovanou většinou a v případě, že dohoda obsahuje ustanovení o jednomyslném přijetí, tak jednomyslně. Když se mezinárodní dohody týkají kultury, vzdělání, zdravotnictví či sociální politiky, pak jsou zahrnuty do sdílené kompetence ES a členských států, a proto pro přijetí takové mezinárodní dohody je třeba jednak rozhodnutí ES a také souhlasu členských zemí s jejím dojednáním. Na dopravu se nevztahuje Článek 133, řídí se totiž speciální úpravou.

Ze zmíněného vyplývá, že orgány ČR nemohou realizovat vưči třetím zemím samostatnou českou zahraničněobchodní politiku, ale že participují př̌i jednáních orgánů ES týkajících se provádění SOP. V důsledku toho bylo nutno vyřešit několik základních otázek:

- Převedení části zákonodárné iniciativy vlády ČR na Komisi EU a části zákonodárné moci na Radu a Evropský parlament.

- Provádění komunitárních obchodně politických právních předpisů. Zároveň ČR ukončí provádění veškerých dohod se třetími zeměmi, které nejsou kompatibilní se členstvím v EU. Některé z nich bude nutné vypovědět, jiné stačí renegociovat k datu vstupu ČR do EU.

- Členství ČR ve WTO bude zachováno, ale dojde ke změně v tom ohledu, že jednajícím subjektem na půdě WTO bude za všechny členské země Komise EU.

- Česká republika bude aplikovat autonomní a smluvní nástroje EU vůči zahraničním partnerům.

Po roce 1989 bylo třeba nově upravit obchodní vztahy s celou řadou zemí a zároveň dojednat dohody se státy, se kterými do té doby Československo nemělo upraveny smluvně své vztahy. Obchodní politika v tomto období byla charakteristická rozsáhlou liberalizací na dvoustranné i mnohostranné úrovni. Mezi nejvýznamnější dohody, uzavřené od počátku 90.let, patří Evropská dohoda, Dohoda o vytvoření Středoevropské zóny volného obchodu, Dohody o vytvoření celní unie se Slovenskem a Dohoda o vytvoření zóny volného obchodu se státy ESVO, na jejichž základě docházelo k postupné liberalizaci vzájemného obchodu, a to především u průmyslových výrobků. ČR uzavřela dohody o volném obchodu s pobaltskými státy (Estonskem, Litvou a Lotyšskem), dále s Tureckem a Izraelem a řadu nepreferenčních dvoustranných smluv.

V souvislosti se členstvím ČR v EU byla tedy nutná harmonizace mezinárodních ekonomických vztahů, a to prostř̌ednictvím přejímání unijních smluv do národní legislativy. Tento proces může mít tři základní typy důsledků pro ČR. Se státy, se kterými má EU sjednanou vyšší úroveň ekonomické spolupráce než ČR před vstupem do EU, přijetí unijní smlouvy pro ČR znamená zjednodušení př́stupu na takový trh. Jestliže ČR i EU měly sjednanou smlouvu stejné úrovně, pak se očekávají jen minimální změny. K mírnému zhoršení př́stupu na některé trhy spiśs než z důvodu vyšší úrovně ekonomické spolupráce ČR před vstupem do EU s určitými státy v porovnání s EU dochází u vybraných komodit, které do doby vstupu ČR do EU ve vztahu k ČR nebyly klasifikovány jako citlivé.

Se vstupem České republiky do EU také souvisí ukončení smlouvy o vytvoření celní unie mezi ČR a Slovenskou republikou, dále přestaly platit další smlouvy. Byla také změněna spolupráce ČR a zemív rámci dohody CEFTA a dohoda o volném obchodu s ESVO, pobaltskými zeměmi, Tureckem, Izraelem, Chorvatskem. To pro Českou republiku neznamená jen ztráty, protože získává dobrý přístup na zahraniční trhy převzetím dohod uzavřených s EU. Tím by se měly zlepšit podmínky našich podnikatelských subjektů na zahraničních trzích a otevřít nové exportní příležitosti. Vnitřní trh EU poskytuje možnost 
podnikat ve stabilním podnikatelském prostředí, kde je zajištěna vysoká úroveň dodržování pravidel hospodářské soutěže, právní ochrana podnikání, nové př́ležitosti vytváří také široký prostor pro podnikání. Mezi důležité úkoly patřila př́íprava podnikatelské sféry na vstup ĆR do EU, prostřednictvím zajištění informací o změnách v zahraničněobchodní politice a vytvoření podmínek pro adaptaci podnikatelů na změny.

\section{Mnohostranné vztahy}

\section{Světová obchodní organizace (WTO)}

Smluvně závazná pravidla v oblastech obchodu zbožím a službami jsou pro ČR upraveny na základě zásad WTO. ČR členství v GATT a WTO pomohlo ke zvýšení transparentnosti obchodně politického režimu ČR a dále to zvyšuje kredit země v zahraničí. Značnou část dosud probíhajícího kola jednání týkající se otázek zlepšení podmínek př́ístupu na trh zbožím a služeb a zpřesnění existujících pravidel a tvorbu nových mnohostranných pravidel projednávala ČR jako samostatný subjekt. S ohledem na očekávaný vstup ČR do EU ale probíhala jednání už v koordinaci s orgány EU, jednotlivými členskými státy a ve spolupráci s kandidátskými státy. Všechny kandidátské země včetně ČR posílily spolupráci s institucemi EU zejména po podpisu Smlouvy o přistoupení.

I dosud, kdy ČR vystupovala v rámci jednání WTO samostatně, mnohé prosazované pozice se shodovaly s myšlenkami podporovanými EU. At už šlo o zlepšování podmínek př́istupu na trh a zájem na vytvoření nových mnohostranných pravidel. V následujícím období bude ČR zejména usilovat o to, aby př́ípadné závazky vyplývající ze členství ve WTO nebyly $\mathrm{v}$ rozporu s podmínkami př́stupu k nástrojům a mechanismům financování EU. Dalším významným prvkem bude zesílená spolupráce ČR s unijními orgány a členskými státy v oblasti obchodní politiky. Mnoho oblastí, které jsou opatřeny dohodami WTO, je v pravomoci Evropské komise. To ale neznamená, že by členské země EU nemohly výrazně ovlivňovat jednání v rámci WTO. Existuje totiž možnost pro jednotlivé státy EU participovat na rozhodnutích prostřednictvím negociátorů Komise. Další oblasti, které nejsou zcela zahrnuty do kompetence Komise, budou pravděpodobně i nadále řešeny na úrovni Stálé mise ČR při WTO a jiných mezinárodních organizacív Ženevě. Podobně jsou totiž články nespadající do kompetence Evropské komise řešeny i stávajícími členskými státy EU.

\section{Vztah k Organizaci pro ekonomickou spolupráci a rozvoj (OECD)}

Členstvív OECD je důležité hlavně z důvodu možnosti podílet se na vytváření společných principů mezinárodní spolupráce v oblasti světového obchodu a přináší ČR uznání jako transparentní země. Pravidelně opakované analýzy na základě tzv. Ekonomického přehledu, ve kterých je zkoumán ekonomický a vývozní potenciál zemí, jsou k dispozici nejen členským zemím OECD, ale i státům, které stojí mimo tuto organizaci. OECD, jakožto významný zdroj expertních analýz a fórum rozvinutých zemí pro projednávání otázek mnohostranného obchodního systému a liberalizaci mezinárodního obchodu a investic přispívá $\mathrm{k}$ hodnocení situace, hledání řešení a postupů a tím $\mathrm{k}$ snazšímu průběhu jednání $\mathrm{v}$ rámci WTO. Probíraná problematika mívá úzkou návaznost na témata, jimiž se zabývá WTO, takže v současné době jde především o otázky obsažené v Rozvojovém programu z Dauhá.

Podstatná je též účast ČR ve skupině Participantů v Ujednání o pravidlech pro státem podporované vývozní úvěry OECD (tzv. Konsensus OECD), což je významný orgán v ob- 
lasti obchodní politiky. ${ }^{4}$ Participace ČR přináší možnost zapojit se do stanovování pravidel státem podporovaného exportu. Z tohoto členství vyplývá také nutnost implementace přijatých pravidel na půdě Participantů do české legislativy. Zapojení ČR do tzv. Konsensu OECD poskytuje zpětnou vazbu a informace týkající se teritoriální a strukturální analýzy podporovaných investičních projektů. Pozitivním efektem pak je také jakési zvýšení důvěryhodnosti země, možnost podílet se na rozhodování v rámci Konsensu OECD a realizace zvýhodněného exportního financování, které ovšem podléhá splnění veškerých podmínek. Po vstupu do EU nemůže ČR vystupovat ve skupině Participantů samostatně, nýbrž svá stanoviska předkládá a obhajuje v rámci koordinačních schůzek a společné pozice pak ve skupině Participantů prezentuje Evropská komise.

Při ostatních jednáních v OECD je zastoupena EU představitelem Evropské komise. I tak mají možnost členské země EU vystupovat svým jménem v rámci negociací o jednotlivých otázkách. Tato možnost platí i pro ČR poté, co se začlenila do Evropské unie.

\section{Středoevropská dohoda o volném obchodu (CEFTA)}

Středoevropská dohoda o volném obchodu (CEFTA) vznikla dohodou mezi ČR, Mad'arskem,Polskou republikou a Slovenskou republikou, podepsanou v prosinci 1992. Byla ratifikována jako otevřené seskupení a v následujících letech se připojily další země: Slovinsko (1996), Rumunsko (1997), Bulharsko (1999) a Chorvatsko (2003). Jde o státy, které patří mezi tradiční obchodní partnery ČR. Vzájemná spolupráce vychází z geografické polohy zemí, podobností ekonomického a politického vývoje a také kulturního zázemí.

Cílem této dohody bylo vytvoření zóny volného obchodu mezi zúčastněnými státy. Postupně docházelo ke vzájemnému snižování cel a množstevních omezení, které proběhlo ve třech fázích. Hned po podpisu dohody byla odstraněna cla u $60 \%$ celních položek. $\mathrm{V}$ druhé fázi byla pak snížena cla u středně citlivých položek, pak i u citlivých položek. Přičemž snižování cel probíhalo symetricky a postupně. Tradičně problematickým bodem jednání se stalo zemědělství. V této citlivé oblasti bylo nakonec dojednáno postupné snižování cel na zemědělské výrobky při současném zachování systému kvót, které působí jako omezující prvek vývozu zemědělských produktů v rámci obchodu CEFTA. ČR se zasazovala o další postup liberalizace vzájemného obchodu s agrární výrobou s tím, že souhlasila s respektováním doporučení Společného výboru dohody CEFTA ${ }^{5}$, které obsahovalo možnost další liberalizace vzájemného obchodu se zemědělskými výrobky na bilaterální úrovni. Protože státy, které se staly členskými zeměmi EU, tedy ČR, Slovenská republika, Mad'arskoPolsko, Slovinsko, od doby začlenění do EU realizují své vztahy na stejném principu jako s ostatními státy EU, vzájemné vztahy probíhají v souladu se zásadami jednotného vnitřního trhu. A pokud se týká Bulharska, Rumunska a Chorvatska, členských zemí CEFTA, které k 1. květnu 2004 nevstoupily do EU, tak vǔči těmto státům přijala ČR stejně jako ostatní nově přistupující země závazky, jež vyplývají z dohod s těmito státy uzavřenými Evropskou unií.

Otázkou je, do jaké míry změna obchodního režimu ovlivní vzájemný obchod se členy CEFTA, které nejsou od května 2004 členy EU. V př́ípadě obchodu ČR s Bulharskem a Rumunskem se neočekávají výraznější změny, protože nejsou žádným podstatným způsobem měněny podmínky obchodu, jen s výjimkou válcových materiálů a textilu. Pravděpodobně dojde $\mathrm{k}$ znesnadnění přístupu českých výrobků na trh v Chorvatsku v důsledku

4 V březnu 1998 bylo rozhodnuto o přijetí ČR do skupiny účastníků Konsensu OECD s účinností od září 1998. Statut pozorovatele byl orientačně stanoven na dobu dvou let a v prosinci 2001 ČR získala řádné členství ve skupině Participantů.

5 Zasedání společného výboru dohody CEFTA se konalo v listopadu 2001 v Bukurešti. 
asymetrických celních preferencí. ${ }^{6}$ Po vstupu ČR do EU jsou používány celní sazby EU, které u zemědělských výrobků v porovnání s českými celními sazbami před vstupem do EU jsou vyšší.

Tab. č. 1: Teritoriální struktura zahraničního obchodu ČR v letech 1995-2002

\begin{tabular}{|c|c|c|c|c|c|c|c|c|}
\hline \multicolumn{9}{|c|}{ Vývoz ČR v \% } \\
\hline rok & 1995 & 1996 & 1997 & 1998 & 1999 & 2000 & 2001 & 2002 \\
\hline VTE & 66,6 & 63,6 & 65,2 & 69,1 & 74,6 & 74,8 & 75,2 & 75,1 \\
\hline EU & 60,9 & 58,2 & 59,9 & 64,2 & 69,2 & 68,5 & 68,9 & 68,4 \\
\hline $\mathrm{TE}$ & 28,8 & 30,3 & 29,5 & 26,3 & 21,8 & 21,1 & 21,2 & 20,8 \\
\hline CEFTA & 21,6 & 23,1 & 21,1 & 19,9 & 17,8 & 16,9 & 17,0 & 16,6 \\
\hline $\mathrm{RZ}$ & 5,4 & 5,6 & 4,9 & 4,2 & 3,2 & 3,8 & 3,3 & 3,5 \\
\hline \multicolumn{9}{|c|}{ Dovoz ČR v \% } \\
\hline rok & 1995 & 1996 & 1997 & 1998 & 1999 & 2000 & 2001 & 2002 \\
\hline VTE & 69,2 & 70,3 & 70,2 & 72,1 & 73,8 & 71,9 & 71,5 & 69,4 \\
\hline EU & 61,1 & 62,4 & 61,5 & 63,4 & 64,2 & 62,0 & 61,8 & 60,2 \\
\hline $\mathrm{TE}$ & 25,5 & 23,4 & 23,3 & 21,1 & 19,4 & 21,0 & 19,9 & 18,5 \\
\hline CEFTA & 16,4 & 14,6 & 14,9 & 14,4 & 13,1 & 12,8 & 12,6 & 12,1 \\
\hline $\mathrm{RZ}$ & 4,4 & 5,5 & 4,9 & 4,9 & 4,4 & 4,6 & 5,4 & 7,3 \\
\hline Poznámka & $\begin{array}{ll}\text { VTE } & \text { vyspěl } \\
\text { TE } & \text { transf } \\
\text { RZ } & \text { rozvo }\end{array}$ & $\begin{array}{l}\text { tržní ekon } \\
\text { mující se } \\
\text { vé země }\end{array}$ & $\begin{array}{l}\text { miky } \\
\text { onomiky }\end{array}$ & & & & & \\
\hline
\end{tabular}

Z tabulek je zřejmé, že z celkového vývozu ČR na země CEFTA připadal z počátku druhé poloviny 90 . let podíl přesahující $20 \%$, v posledních letech docházelo k poklesu podílu připadajícího na země CEFTA. Naopak se posilovala obchodní výměna s vyspělými tržními ekonomikami, velký podíl př́růstku připadal na země EU. Podíl českého dovozu do zemí CEFTA se od poloviny 90 . let do současnosti pohyboval od 16,4 \% do $12,1 \%$. Přičemž lze zaznamenat podobný trend jako v př́ípadě exportu. Podíl českého dovozu do zemí CEFTA klesal.

Zastoupení jednotlivých zemí na obratu zahraničního obchodu (ZO) ČR nám naznačuje následující tabulka. Největší obchodní výměna probíhá mezi ČR a Slovenskem, nebot? se Slovenskem nás vážou tradiční vazby. S cílem o co nejmenší narušení obchodních styků po rozdělení ČSFR byla vytvořena celní unie mezi Českou republikou a Slovenskou republikou. Zvláštností bylo, že se státy mohly samostatně angažovat v mezinárodních ekonomických vztazích a přijímat mezinárodní závazky. Druhým nejvýznamnějším obchodním partnerem pro ČR je Polsko.

6 Na některé komodity dovážené z EU Chorvatsko uvaluje cla, přičemž ale dovozy z Chorvatska do EU jsou bezcelní. 
Tab. č. 2: Zahraniční obchod ČR s jednotlivými státy CEFTA

\begin{tabular}{|l|r|r|r|r|r|r|r|r|}
\hline \multirow{2}{*}{$\begin{array}{l}\text { Země, } \\
\text { region }\end{array}$} & \multicolumn{2}{|c|}{ ČR r. 1999 } & \multicolumn{2}{c|}{ ČR r. 2000 } & \multicolumn{2}{c|}{ ČR r. 2001 } & \multicolumn{2}{c|}{ ČR r. 2002 } \\
\cline { 2 - 9 } & $\begin{array}{c}\text { obrat } \\
\text { ZO }\end{array}$ & \multicolumn{1}{c|}{$\begin{array}{c}\text { podíl } \\
\text { v \% }\end{array}$} & $\begin{array}{c}\text { obrat } \\
\text { ZO }\end{array}$ & $\begin{array}{c}\text { podíl } \\
\text { v \% }\end{array}$ & $\begin{array}{c}\text { obrat } \\
\text { ZO }\end{array}$ & $\begin{array}{c}\text { podíl } \\
\text { v \% }\end{array}$ & $\begin{array}{c}\text { obrat } \\
\text { ZO }\end{array}$ & $\begin{array}{c}\text { podíl } \\
\text { v \% }\end{array}$ \\
\hline Mad'arsko & \multicolumn{1}{|c|}{31955} & 5,10 & 40905 & 4,96 & 48013 & 5,21 & 56252 & 5,80 \\
\hline Polsko & 85772 & 13,69 & 105234 & 12,77 & 117803 & 12,78 & 112262 & 11,58 \\
\hline Slovensko & 136222 & 21,74 & 160653 & 19,50 & 176495 & 19,15 & 165781 & 17,11 \\
\hline Rumunsko & 5603 & 0,89 & 7751 & 0,94 & 11046 & 1,20 & 11797 & 1,22 \\
\hline Bulharsko & 4112 & 0,66 & 4743 & 0,58 & 4806 & 0,52 & 5064 & 0,52 \\
\hline Chorvatsko & 5837 & 0,93 & 7402 & 0,90 & 8648 & 0,94 & 9190 & 0,95 \\
\hline Slovinsko & 15445 & 2,47 & 16109 & 1,96 & 16283 & 1,77 & 15952 & 1,65 \\
\hline
\end{tabular}

Pramen: FACTS ON FOREIGN TRADE OF THE CZECH REPUBLIC 2001 a 2003.

\section{Vztah ČR ke členským zemím EU}

Vzájemný vztah ČR a členských zemí EU byl v období před vstupem ČR určen Evropskou dohodou zakládající přidružení mezi ČR a EU a jejími členskými státy. Obchodní část této dohody zahrnuje soubor principů a opatření, včetně časového plánu, vedoucích k postupné liberalizaci obchodu. U průmyslových výrobků byly splněny původně předsevzaté termíny liberalizace k 1.1.2001. Byly odstraněny celní překážky i množstevní omezení. Zvlášè byla dojednána liberalizace obchodu se zemědělskými produkty, kde nebyla předpokládána plná liberalizace a odstranění cel a byla dojednána možnost poskytnutí koncesí. Všechny domluvené koncese pro nezpracované zemědělské výrobky byly shrnuty do jednoho dokumentu, Protokolu k Evropské dohodě, který vstoupil v platnost 1. května 2003.

Počínaje květnem 2004 se ČR stala součástí jednotného vnitřního trhu EU. Vzájemný obchod s dalšími 24 členskými státy není klasifikován jako zahraniční obchod, ale jde o vnitrounijní obchod, který se řídí zásadami jednotného trhu s volným pohybem zboží, služeb, kapitálu a osob, ovšem s určitými dočasně trvajícími výjimkami. Nejsou aplikována žádná cla, poplatky a další opatření, která by fungovala jako tarifní bariéra obchodu. Jsou tedy zrušeny celní kontroly pohybu zboží na hranicích se členskými státy EU, je však třeba při přechodu zboží přes hranice vyplnit formulář pro účely společné obchodní politiky a sledování statistických údajů, Intrastat. Díky osvobození od vybírání cel a poplatků je zjednodušena práce Celní správy ČR.

ČR přijala celní sazebník EU. U některých položek došlo ke snížení celní sazby, jiné nezaznamenaly výraznější změny a u ostatních, zejména u zemědělských komodit se zvýšily celní sazby.

Zatím i nadále bude prováděna kontrola na hranicích Policií ČR, ale to do té doby, dokud se ČR nestane součástí Schengenského systému.

Při obchodování se třetími státy, mimo EU, je uplatňován společný celní sazebník. Celní sazby jsou určovány na základě rozhodnutí orgánů EU a prostřednictvím dohod uzavřených v rámci WTO a také dvoustranným jednáním s určitými zeměmi.

7 V dubnu 2003 byly dojednány koncese pro zpracované zemědělské výrobky, dále koncese pro obchod s rybami a rybími výrobky, oboustranné koncese na víno. 


\section{Obchodní vztahy ČR ke třetím zemím}

Samozřejmě i podoba dvoustranných zahraničně obchodních vztahů je ovlivněna vstupem ČR do EU. Omylem by bylo domnívat se, že tyto vztahy jsou nějakým způsobem potlačeny nebo úplně omezeny. Jde spíše o jejich transformaci, a to právě tak, aby byly v souladu se společnou obchodní politikou a aby se vzájemně doplňovaly a utvářely funkční systém. Úkolem pro nastávající období bude vytvořit vhodné prostředí pro rozvoj bilaterálních vztahů s nečlenskými státy EU při současném dodržování závazků a pravidel platných pro EU.

\subsection{Vztah ČR k Evropskému sdružení volného obchodu (ESVO)}

Dohoda o volném obchodu mezi ČSFR a státy ESVO byla podepsána v březnu 1992 v Praze. Po rozdělení ČSFR na dva samostatné státy sukcedovaly ČR a Slovenská republika do této dohody.

Přestože se podíl zemí ESVO na obratu zahraničního obchodu ČR v posledních letech pohyboval pouze kolem 2,2-2,3\%, patří členské země ESVO mezi významné obchodně politické partnery ČR. Jedním z důvodu jsou i dodávky norského zemního plynu. Vztah mezi ČR a členskými státy ESVO byl před vstupem do EU upraven dle Dohody o volném obchodu mezi ČR a státy ESVO. Zmíněná dohoda zahrnovala vzájemný obchod s průmyslovými výrobky, rybami a některými zpracovanými zemědělskými produkty. Jinak obchod se zemědělskými výrobky byl prováděn na základě bilaterálních dohod mezi ČR a jednotlivými státy ESVO. Liberalizace obchodu s průmyslovým zbožím mezi ČR a ESVO bylo dosaženo k 1. lednu 2001, a tak probíhá zcela bezcelně a bez omezení. Na vybrané zpracované zemědělské výrobky si ČR a ESVO poskytovaly určité preference, které mívaly formu nulové celní sazby, a pokud se týká zemědělských výrobků, jejichž obchod byl upraven v rámci bilaterálních dohod, tak Švýcarsko, Island a Norsko jednostranně poskytovaly koncese pro ČR. Úprava závisela na podobě jednotlivých smluv. Např́klad Norsko na vyjmenované zemědělské produkty poskytovalo nulové clo, na jiné $50 \%$ snížení celního tarifu. Toto snižení se týkalo např́ḱlad zeleniny, ovoce, mouky, krupice, semen a podobně.

V souvislosti se vstupem ČR do EU byla platnost Dohody mezi ČR a ESVO ukončena k 30. dubnu 2004 a vzájemné vztahy se řídí Dohodou o Evropském hospodářském prostoru (EHP) na základě členství ČR v EHP. Tím došlo k rozšíření podmínek jednotného vnitřního trhu EU na trh Norska, Lichtenštejnska a Islandu. Stranou EHP zůstává další člen ESVO - Švýcarsko, a proto ČR převzala vstupem do EU smluvní režim EU vǔči Švýcarsku, který vychází ze sedmi bilaterálních smluv.

Na základě již dosaženého stupně liberalizace na úrovni zóny volného obchodu u průmyslové výroby nedošlo u těchto komodit pro ČR v důsledku začlenění do EU ve vztahu k zemím ESVO k žádným výrazným změnám.

\subsection{Pobaltské státy}

Obchodní vztahy ČR se skupinou pobaltských států byla před naším vstupe do EU upraveny na základě dvoustranných dohod: Dohoda o obchodu mezi ČR a Lotyšskou republikou (vstoupila v platnost v zář́ 1997), Dohoda o volném obchodu mezi ČR a Litevskou republikou (vstoupila v platnost v červenci 1997), Dohoda o volném obchodu mezi ČR a Estonskou republikou (vstoupila v platnost $v$ únoru 1998). Tyto dohody přispěly k liberalizaci vzájemného obchodu s průmyslovými a zemědělskými výrobky. K hlubší liberalizaci obchodu se zemědělskými a potravinářskými výrobky došlo v př́ípadě Estonska, které 
rozhodlo neuplatňovat žádná dovozní cla na tyto produkty. ČR podobnou velkorysou nabídku neučinila. Jen se zavázala, že postupně bude rozšiřovat počet liberalizovaných položek. Na základě rozhodnutí Společného výboru Dohody o volném obchodu mezi ČR a Estonskem byly sjednány nové zemědělské koncese, které vyrovnávaly liberalizaci ve vzájemném obchodě se zemědělskými a potravinářskými komoditami. Podobný proces další liberalizace nebyl uskutečněn ani ve vztahu s Lotyšskem a Litvou, a to zejména s ohledem na společný termín vstupu všech pobaltských zemí i ČR do EU. Po vstupu do EU jsou všechny jmenované země součástí jednotného vnitřního trhu.

\subsection{Země Společenství nezávislých států (SNS)}

Jelikož především Ruská federace je pro naši zemi jedním z důležitých dodavatelů ropy a zemního plynu a také odběratelem českých strojů a zařízení, je zájem na podpoře vzájemných bilaterálních vztahů nejen s Ruskou federací, ale i s dalšími státy SNS. Proto byly uzavřeny obchodní dohody s Ázerbájdžánem, Běloruskem, Kazachstánem, Kyrgyzstánem, Moldavskem, Ruskou federací, Tádžikistánem, Turkmenistánem, Ukrajinou a Uzbekistánem. Přičemž šlo o standardní obchodně politické dohody, nikoli preferenční. Jednotlivé státy si poskytovaly recipročně doložku nejvyšších výhod dle zásad WTO.

Po začlenění ČR do EU se vztahy mezi ČR, jakožto člena EU, a státy SNS realizují podle obchodně politických režimů EU. Takže dosavadní smlouvy byly vypovězeny a budou uzavřeny v př́ípadě zájmu nové dvoustranné dohody, jež budou upravovat hospodářskou spolupráci jednotlivých zemí. Všechny nově uzavřené dohody samozřejmě nesmí být $\mathrm{v}$ rozporu s pravidly EU.

Rusko a státy SNS uzavřely s EU na deset let Dohodu o partnerství a spolupráci (PCA - Partnership and Cooperation Agreement), jež se týká poskytnutí doložky nejvyšších výhod a režimu národního zacházení dovozcủm z těchto zemí uvnitř EU a též politických aspektů. EU neodmítá budoucí začlenění Ruska do WTO a v dlouhodobějším horizontu se uvažuje o uzavření dohod o volném obchodu s Ruskou federací.

Změna celních sazeb souvisejících s převzetím celního sazebníku EU povede ke komplikacím při př́stupu zboží ze SNS na český trh. Nemělo by ale dojít k výrazným problémům, protože pro dovoz zboží z tohoto teritoria budou uplatňovány úlevy podle GSP.

\subsection{Státy jihovýchodní Evropy}

Jedná se o státy bývalé Jugoslávie. Zahraničně obchodní otázky byly před naším vstupem do EU s jednotlivými státy této oblasti upraveny různě. Slovinsko bylo členem CEFTA, od března roku 2003 se prováděla Dohoda o př́stupu Chorvatské republiky ke Středoevropské dohodě o volném obchodu. Vztahy s Albánií byly upraveny prostřednictvím Dohody o obchodně ekonomických vztazích a spolupráci ve vědě a technice. S ostatními státy - Srbskem a Černou Horou, Makedonií a Bosnou a Hercegovinou uzavřela ČR obchodní dohody.

Do EU ze zmíněné skupiny zemí vstoupilo jen Slovinsko. Je zřejmé, že od května 2004 se bilaterální styky ČR řídí podle obchodně politických režimů EU ve vztahu ke konkrétním zemím v této oblasti. I nadále se však počítá s bližši spoluprací ČR se státy jihovýchodní Evropy, především z důvodu podpory konkrétních projektů a zvýšení českého exportu. 


\subsection{Dvoustranné vztahy s mimoevropskými zeměmi}

Ačkoli v současné době je podíl zahraničně obchodní výměny ČR s mimoevropskými zeměmi dost nízký, nelze jej zcela zanedbávat.

Ještě na sklonku 80. let byl obchod silně orientován na země bývalé RVHP. V rámci transformačního procesu došlo k výrazné přeorientaci zahraničního obchodu ČR, a to na trhy vyspělých tržních ekonomik, zejména na trhy členských zemí EU.

Tab. č. 3: Teritoriální struktura čs. zahraničního obchodu

\begin{tabular}{|l|r|r|r|}
\hline \multicolumn{4}{|c|}{ Čs. vývoz v procentech (\%) } \\
\hline & \multicolumn{1}{|c|}{$\mathbf{1 9 8 9}$} & \multicolumn{1}{c|}{$\mathbf{1 9 9 3}$} & \multicolumn{1}{c|}{$\mathbf{1 9 9 8}$} \\
\hline CPE & 50,00 & 35,00 & 26,30 \\
\hline VTE & 37,20 & 57,40 & 69,10 \\
\hline EU & 31,90 & 52,70 & 64,20 \\
\hline RZ & 7,50 & 7,80 & 4,90 \\
\hline Poznámka: & CPE centrálně plánované ekonomiky \\
& $\begin{array}{l}\text { VTE vyspělé tržní ekonomiky } \\
\text { RZ rozvojové země }\end{array}$ \\
\end{tabular}

\begin{tabular}{|l|r|r|r|}
\hline \multicolumn{4}{|c|}{ Čs. dovoz v procentech (\%) } \\
\hline & \multicolumn{1}{|c|}{$\mathbf{1 9 8 9}$} & \multicolumn{1}{c|}{$\mathbf{1 9 9 3}$} & \multicolumn{1}{c|}{$\mathbf{1 9 9 8}$} \\
\hline CPE & 51,30 & 32,60 & 21,10 \\
\hline VTE & 37,00 & 64,10 & 72,00 \\
\hline EU & 31,80 & 56,20 & 63,50 \\
\hline RZ & 7,50 & 4,50 & 4,90 \\
\hline
\end{tabular}

Pramen: Statistické ročenky ČR, ČSÚ.

Zmíněné změny teritoriální struktury byly doprovázeny změnami v komoditní struktuře zahraničního obchodu.

Tab. č. 4: Podíl vývozu dané komoditní skupiny na celkovém vývozu v \%

\begin{tabular}{|r|l|r|r|r|r|r|r|r|r|}
\hline \multicolumn{2}{|c|}{ Skupina zboží podle SITC } & $\mathbf{1 9 8 9}$ & $\mathbf{1 9 9 1}$ & $\mathbf{1 9 9 3}$ & $\mathbf{1 9 9 5}$ & $\mathbf{1 9 9 7}$ & $\mathbf{1 9 9 9}$ & $\mathbf{2 0 0 1}$ & $\mathbf{2 0 0 2}$ \\
\hline 0 & Potraviny a živá zvířata & 4,6 & 7,7 & 6,5 & 4,9 & 3,7 & 2,8 & 2,7 & 2,5 \\
\hline 1 & Nápoje a tabák & 0,4 & 0,9 & 1,2 & 0,8 & 1,3 & 0,8 & 0,7 & 0,7 \\
\hline 2 & Suroviny & 3,7 & 5,3 & 5,9 & 5,2 & 4,0 & 3,7 & 3,0 & 2,8 \\
\hline 3 & Paliva & 5,2 & 4,2 & 6,3 & 4,3 & 3,8 & 2,8 & 3,0 & 2,9 \\
\hline 4 & Oleje a tuky & 0,1 & 0,1 & 0,2 & 0,2 & 0,2 & 0,1 & 0,1 & 0,1 \\
\hline 5 & Chemikálie & 7,6 & 10,6 & 9,4 & 9,3 & 8,8 & 7,2 & 6,4 & 6,0 \\
\hline 6 & Tržní výrobky & 22,4 & 30,5 & 30,3 & 32,2 & 26,8 & 25,5 & 24,4 & 23,3 \\
\hline 7 & Stroje a dopravní prostř́edky & 44,4 & 28,0 & 27,6 & 30,3 & 37,6 & 43,3 & 47,4 & 49,6 \\
\hline 8 & Různé průmyslové výrobky & 9,7 & 12,7 & 12,6 & 12,7 & 13,7 & 13,7 & 12,2 & 11,9 \\
\hline 9 & Nezatř́́děné & 1,9 & 0,0 & 0,0 & 0,1 & 0,1 & 0,1 & 0,1 & 0,2 \\
\hline Celkem 0-9 & 100 & 100 & 100 & 100 & 100 & 100 & 100 & 100 \\
\hline
\end{tabular}

Pramen: Statické ročenky ČR, ČSÚ. 
Tab. č. 5: Podíl dovozu dané komoditní skupiny na celkovém dovozu v \%

\begin{tabular}{|r|l|r|r|r|r|r|r|r|r|}
\hline \multicolumn{2}{|c|}{ Skupina zboží podle SITC } & $\mathbf{1 9 8 9}$ & $\mathbf{1 9 9 1}$ & $\mathbf{1 9 9 3}$ & $\mathbf{1 9 9 5}$ & $\mathbf{1 9 9 7}$ & $\mathbf{1 9 9 9}$ & $\mathbf{2 0 0 1}$ & $\mathbf{2 0 0 2}$ \\
\hline 0 & Potraviny a živá zvíŕata & 6,9 & 5,7 & 6,3 & 5,6 & 5,1 & 4,6 & 3,9 & 4,1 \\
\hline 1 & Nápoje a tabák & 0,7 & 1,2 & 1,1 & 0,8 & 1,0 & 0,8 & 0,5 & 0,5 \\
\hline 2 & Suroviny & 8,8 & 9,2 & 5,0 & 4,5 & 3,7 & 3,1 & 2,9 & 2,9 \\
\hline 3 & Paliva & 17,3 & 29,8 & 11,1 & 7,9 & 8,6 & 6,5 & 9,1 & 7,6 \\
\hline 4 & Oleje a tuky & 0,4 & 0,3 & 0,4 & 0,3 & 0,2 & 0,3 & 0,2 & 0,2 \\
\hline 5 & Chemikálie & 9,3 & 9,8 & 12,1 & 11,8 & 12,1 & 12,0 & 10,9 & 11,1 \\
\hline 6 & Tržní výrobky & 10,4 & 9,1 & 15,9 & 20,2 & 19,2 & 20,6 & 20,2 & 20,6 \\
\hline 7 & Stroje a dopravní prostředky & 36,9 & 28,0 & 36,1 & 37,1 & 38,5 & 40,4 & 42,2 & 42,4 \\
\hline 8 & Různé průmyslové výrobky & 6,2 & 6,8 & 11,7 & 11,8 & 11,5 & 11,7 & 10,1 & 10,6 \\
\hline 9 & Nezatříděné & 3,1 & 0,1 & 0,3 & 0,0 & 0,1 & 0,0 & 0,0 & 0,0 \\
\hline Celkem 0-9 & 100 & 100 & 100 & 100 & 100 & 100 & 100 & 100 \\
\hline
\end{tabular}

Pramen: Statické ročenky ČR, ČSÚ.

Před naším vstupem do EU více než $65 \%$ obratu zahraničního obchodu ČR představoval obchod se státy EU, což může mít až negativní efekty v podobě vzniku závislosti na konjunkturním vývoji nejdůležitějších obchodních partnerů. Proto se domnívám, že diverzifikace našeho obchodu je dost podstatná. Existují možnosti pronikání na trhy asijských zemí, do Latinské Ameriky a do Afriky. Do těchto zemí bývalé Československo hodně vyváželo výrobky a investiční celky a dá se říci, že průmyslové zboží mělo celkem dobré jméno v těchto teritoriích. Zmíněné země představují rozsáhlé mnohamiliónové trhy a též velkou zásobárnu surovin.

Proto byla zahájena dvoustranná jednání a častější návštěvy vládních představitelů do těchto mimoevropských zemí. Posílení spolupráce se týká samozřejmě i obchodních partnerů z Evropy a vyspělých ekonomik světa, které i nadále budou tvořit převažující podíl našeho zahraničního obchodu.

V průběhu 90. let bylo vyvinuto úsilí o novelizaci bilaterálních smluvních vztahů s mimoevropskými státy tak, aby to odpovídalo změněným ekonomickým a politickým podmínkám. S očekávaným vstupem ČR do EU byly připravovány úpravy takové, aby po našem vstupu do EU byla zajištěna kontinuita vzájemné spolupráce se třetími zeměmi na úrovni, která je obvyklá u členských zemí EU a zároveň aby odpovídala pravidlům a zásadám Společné obchodní politiky EU. Po vstupu ČR do EU byly běžné obchodní dohody se třetími zeměmi vypovězeny a ČR, podobně jako další přistoupivší státy, se stala smluvní stranou dohod uzavřených v ekonomické oblasti mezi EU a dalšími státy. ČR si ale bude moci unijní úpravu vztahů se třetími státy doplnit dvoustrannými dohodami, jež se budou týkat jednotlivých oblastí a otázek, které nejsou řešeny na mnohostranné bázi či rámcovými dohodami EU.

\section{Vztahy se státy amerického kontinentu}

Obchod s Kanadou neměla ČR před vstupem do EU upraven bilaterálně, a proto se řídil na základě pravidel plynoucích z Dohody o WTO. V případě USA obchodní otázky vycházely ze zhruba 20 uzavřených dohod. Základem je Dohoda o obchodních vztazích mezi vládou ČSFR a vládou USA z dubna 1990, podle níž byla ČR přiznána nejprve podmíněně a později, od roku 1994, trvale doložka nejvyšších výhod. Pro exportéry z ČR od 
roku 1991 platil Všeobecný systém preferencí umožňující bezcelní dovoz vybraných výrobků do USA. Ten však byl zrušen po vstupu ČR do EU. Podle předběžných propočtů by neměl mít výrazný vliv na strukturu zahraničního obchodu CR. Ale jednotliví exportéri pravděpodobně mohou zaznamenat snížení konkurenční schopnosti v důsledku promítnutí zvýšení celních sazeb do ceny zboží. Zároveň díky existující spolupráci EU s USA a zapojení ČR do vyšších forem spolupráce vzniknou pro české exportéry nové šance a příležitosti.

ČR rovněž před vstupem do EU uzavřela dvoustranné dohody se státy Střední a Jižní Ameriky ${ }^{8}$ a dále se zeměmi Karibské oblasti. Tyto dohody upravovaly vzájemné obchodní vztahy většinou na recipročním základě. Začlenění ČR do EU přinese rožšriření obchodně ekonomických vztahů v této oblasti, protože EU spolupracuje jak s jednotlivými státy Latinské Ameriky a Karibské oblasti, tak s integračními seskupeními, jako je Mercosur a Andské společenství. Posun je možné zaznamenat i hlediska kvalitativního, nebở dohody ČR se zeměmi Latinské Ameriky byly nepreferenční, zatímco cílem dohod EU s některými státy a Mercosurem je vytvoření volného obchodu.

\section{Asijské státy}

Z asijského kontinentu měla ČR před vstupem do EU uzavřeny dohody o obchodu a o otázkách s obchodem souvisejícími se dvaceti státy. Šlo o nepreferenční dohody obsahující pravidla pro vzájemný obchod a zahrnující také doložku nejvyšších výhod a preferenční celní sazby pro státy s rozvojovým statutem. Se státy, kde nebyla navázána žádná dvoustranná dohoda, byly vztahy upraveny na základě pravidel WTO. Pouze s Tureckem byla dojednána dohoda o volném obchodu.

Pokud se týká smluvní úpravy, kterou má EU s asijskými státy, jde většinou o dohody rámcové, jež vymezují obecně oblasti spolupráce a regulují tok zboží do EU. Podrobnější úprava se vztahuje na obchod s textilním zbožím.

\section{Afrika a Blizký Východ}

V rámci tohoto regionu se vztahy ČR s arabskými zeměmi před naším vstupem do EU řídily většinou podle navázaných obchodních dohod. Obsáhlejší úpravu vztahů se Saudskou Arábií zajištovala Všeobecná dohoda. Jedinou preferenční dohodou byla Dohoda o volném obchodu ČR s Izraelem, která odstranila cla na dovoz průmyslových výrobků, u zemědělských komodit a u potravinářského zboží nadále přetrvávala některá tarifní a netarifní omezení.

V př́ipadě vztahů se státy Afriky se uplatňovaly nepreferenční smlouvy, ve kterých byla zakotvena doložka nejvyšších výhod s možností poskytnutí jistých výjimek.

Po vstupu ČR do EU přistoupila ČR k Euro-středomořským asociačním dohodám, jež zabezpečují liberalizaci vzájemného obchodu mezi členy těchto dohod. ČR to přinese nulové celní zatížení dovozu zboží ze středomořské oblasti a dále postupné snižování cel při vývozu ČR do tohoto teritoria.

Série dohod z Lomé byla doplněna dohodou z Cotonou, která upravuje nově vztahy se zeměmi subsaharské Afriky. Dosud vztahy EU k rozvojovým zemím byly organizovány na jednostranném poskytování preferencí. Podle dohody z Cotonou by od roku 2008 měly být stávající dohody nahrazeny dohodami, které by měly reciproční základ.

8 Argentiny, Bolívie, Brazílie, Ekvádor, Guatemala, Honduras, Chile, Kolumbie, Kostarika, Mexiko, Nikaragua, Panama, Paraguay, Peru, Uruguay a Venezuela. 


\section{Závěr}

Vstup České republiky do Evropské unie přinesl přizpůsobení zahraničněpolitického režimu tak, aby byl v souladu s unijní úpravou. To platí i pro obchodní oblast, kde došlo k přesunu kompetencí z národních úřadů na instituce EU. Státní orgány České republiky už nepřipravují samostatnou obchodní politiku, ale aktivně se podílejí na formování společné obchodní politiku EU, která je pak uplatňována vůči třetím zemím.

Převzetím komunitárních obchodně politických předpisů se ukončila platnost národních právních předpisů, zároveň se ČR stala smluvní stranou mezinárodních dohod uzavřených Evropskými společenstvími s nečlenskými státy. V souvislosti s tím došlo k ukončení veškerých dohod, které nebyly kompatibilní se členstvím v EU.

Změny vyvolané nutností přizpůsobit se unijním předpisům a ustanovením smluv, které má uzavřené EU s třetími státy, budou mít pravděpodobně z větší části téměř neutrální vliv na přístup na zahraniční trhy. Jak z textu vyplývá, ve vztahu k některým teritoriím se očekává zlepšení, ve vztahu k jiným naopak zhoršení, a to v závislosti na úrovni spolupráce Č́R s danými státy či skupinami států před vstupem ČR do EU v porovnání se smluvní úpravou, kterou má Evropská unie.

Na mikroekonomické úrovni je zřejmé, že bylo nutné přizpůsobení všech subjektů v ekonomice novým podmínkám. Současně roste potřeba informací o změnách v zahraničněobchodní politice a jejich důsledků pro podnikatelskou sféru.

\section{Literatura}

1. HŘíCH, J.: Česká zahraničně obchodní politika a EU. Praha, Institut mezinárodních vztahů, 2000.

2. PLCHOVÁ, B. - LUKÁŠ, Z. - HRADOVÁ, M.: Česká republika a Evropská unie. VŠE Praha, 2002.

3. PLCHOVÁ B.: Zahraničněobchodníaspekty vývoje konkurenceschopnosti ČR na cestě do EU. IČRE, 2003.

4. PLCHOVÁ, B.: Harmonizing Trade Policy of the Czech Republic with Trade Policy of EU. Lisabon, CEDIN, 2001.

5. KUBIŠTA, V. a kol.: Mezinárodní ekonomické vztahy. HZ Editio, 1999.

6. VAVREJNOVÁ, M.: Harmonizace obchodní politiky ČR s obchodní politikou zemí EU a možný dopad na komparativní výhody zahraničního obchodu CR. Discussion Paper, No. 1999-31, CERGE-EI.

7. HAD, M. - URBAN L.: První piliř Evropské unie. Praha, Ministerstvo zahraničních věcí, 2000.

8. Statistické ročenky ČR, ČSÚ.

9. Facts on Foreign Trade of the Czech Republic 2001, 2003.

Internet:

www.wto.org

www.mpo.cz

www.cefta.org

www.europa.eu.int

www.cs.mfcr.cz 